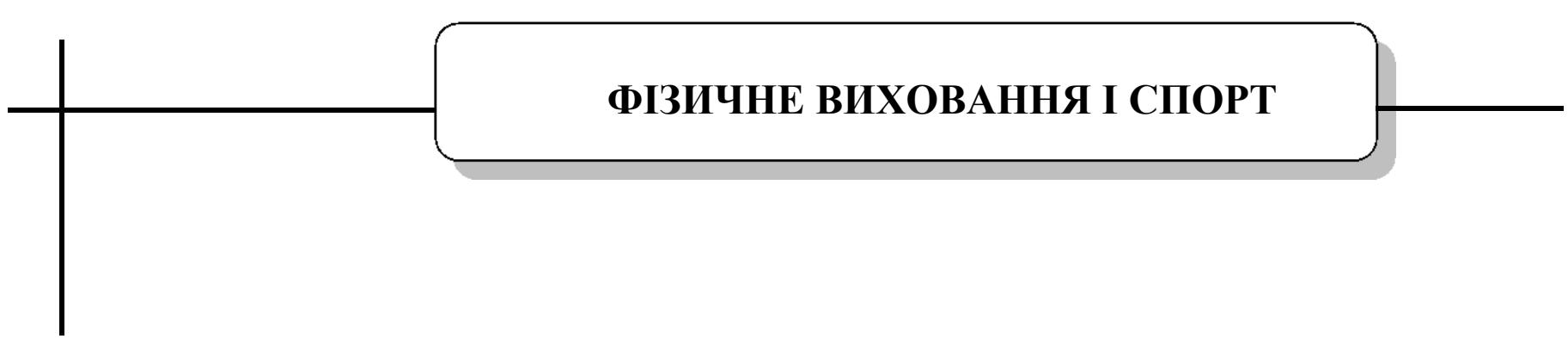

UDC 372.8

DOI: $10.15587 / 2313-8416.2019 .174318$

\title{
EFFECT OF PROGRESSIVE AND REPETITIVE PART METHODS AGAINST THE ACCURACY OF KICKING IN FOOTBALL EXTRACURRICULAR STUDENTS
}

\author{
Ardian Rahman, Suharjana, Erick Burhaein
}

The aim of the study was to determine the differences in the effect of the progressive and repetitive part method on the accuracy of the long pass kicks of the High School Football Extracurricular Students. Subject Research 30 athletes. There is a difference in the effect of the progressive part method and the repetitive part method on the accuracy of the long pass kicks of the High School Football Extracurricular Students. The repetitive part method has a better influence than the progressive part method for the accuracy of the long pass kicks of the High School Football Extracurricular Students

Keywords: Precision of The Stomach Kick, Progressive Part Method, Repetitive Part Method

Copyright (C) 2019, Ardian Rahman, Suharjana, Erick Burhaein. This is an open access article under the CC BY license (http://creativecommons.org/licenses/by/4.0).

\section{Introduction}

Efforts to improve sports performance in schools continue to be carried out in order to improve sports achievements, include guidance, nursery, talent scouting, improvement of infrastructure and facilities, and the application of science and technology in research $[1,2]$.

Development of sports achievement needs to start early [3]. The development of sports in Indonesia started a lot from schools, namely through sports and health physical education subjects. Sports is one lesson that is very suitable for education [4]. Exercise is beneficial in psychomotor formation, cognitive and affective development will also be well formed $[2,5,6]$. Besides that the main goal is to improve the health of students, with the condition of healthy and strong students expected to be the backbone of a quality country.

Sports games are the most popular type of sport for students, one of which is football [7]. Football games are a type of sport that is very interesting to develop among students. Football games are a type of sport that is quite popular in schools [8]. Nurkhasan [9], In the Sukoharjo district itself, football games have become popular in the community. The large number of facilities built and various match events that have been held, is proof that football games have a place in the community of Sukoharjo Regency [9]. In the scope of institutions, namely at the level of junior high and high school and vocational school, foot- ball games have also become part of learning activities and extracurricular activities.

Nurkhasan [9], seeing the development of football sports in high school in the Sukoharjo Regency area, there are still schools that need guidance especially on the mastery aspects of basic techniques, namely in high school extracurricular football students. The inter-student tournament which has been followed several times, it can be seen that the high school extracurricular football students still lack the mastery of the basic techniques of ball kicks, especially on long pass kicks [9].

\section{Literature review}

Mastery of the ability of the ball kick technique, especially the long pass ball in high school students, is still lacking [10]. This was seen during the game, many players made a mistake in making a ball kick bait. It is often seen that the kicked ball does not match the target of the intended player and the ball is not perfectly lifted or soar low. Thus the ability of long pass kicks of high school extracurricular football students must be improved $[11,12]$.

In order to be able to do a long pass well, the technique of doing a stomach kick must be in accordance with the theory and practice of a good and correct stomach kick [13]. To increase the accuracy of long pass kicks of extracurricular football students Upper High School needs to get priority in learning. Mastery of the 
accuracy of stomach kicks can be achieved by doing learning systematically and continuously [14]. Some methods that can be applied to improve the precision of long pass kicks include: individual and pair training, extensive and intensive methods, massed practice and distributed practice and part methods. In this case the researcher will use the part method.

The appropriate form of training to train the precision of long pass kicks is to use the part method. This is based on the different abilities of each individual. There are those who need several repetitions in order to master a movement and some need only a little repetition to be able to master the techniques taught. This also relates to the talent possessed by the player itself.

Part method is a method that separates the parts of a technical movement so that it can be mastered in an easier way [15]. Part method can be divided into two, namely progressively and repetitively. Briefly, the progressive part method emphasizes the practice of mastering the techniques step by step which must be mastered with a higher level of ability [16]. While the repetitive part method combines the forms of training that must be mastered with different levels of difficulty in one stage of practice [17]. The progressive and repetitive part method is a method that can be used to train long pass kicks techniques in football games. Each of these training models has strengths and weaknesses, so it is not yet known which training method has better effect on increasing the accuracy of the long pass kicks of the High School Football Extracurricular Students.

\section{The aim and objectives of research}

The aim of this research is the differences in the effect of the progressive and repetitive part method on the accuracy of the long pass kicks of the High School Football Extracurricular Students.

To accomplish the aim, the following objectives have been set:

1. To provide information about the differences in the effect of the progressive and repetitive part method on the accuracy of the long pass kicks of the High School Football Extracurricular Students.

2. To provide information about which method gives a greater effect on the long pass kicking.

\section{Research Methods}

\subsection{Subjects}

The subject is a high school football athlete so it has the experience of football. Researchers focus on subjects who have football experience only. The research subjects were male with a total of 30 athletes.

\subsection{Ethics}

This study has the approval of the ethics committee to conduct experimental studies on subjects aged 16 and 17 years.

\subsection{Procedure}

The research method used is the experimental method, that begins by giving treatment to the subject which ends with a test to determine the effect of the treatment given. The pretest-posttest design research design [18] no control group in this research in this study is shown in Fig. 1.

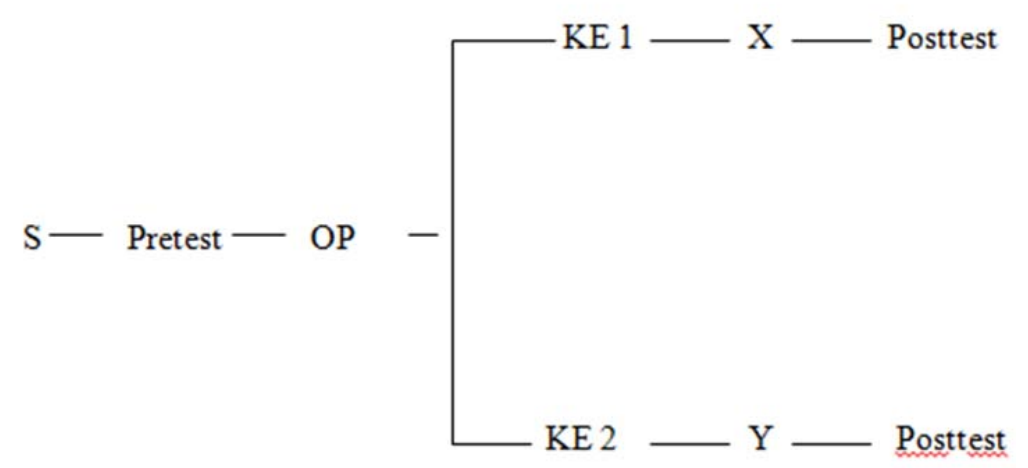

Fig. 1. Design of Experimental Research: S - Subject; OP - Ordinal Pairing; KE1 - Experiment Group 1; KE2 - Experiment Group 2; X - Procedure Method 1; Y - Procedure Method 2

Subjects are separated into two groups using ordinal pairing after initial test, so that both groups have balanced skills. The division of groups in this study are as follows (Fig. 2).

Variables sample: In accordance with the title of this study, this study consisted of two variables. The research variable consists of: (1) independent variables in this study consist of: (a) stomach kick exercise using the progressive part method; (b) stomach kick exercises using the repetitive part method; (c) are influenced by other variables; and (2) dependent variable in this study is the accuracy of a football long pass kicks.

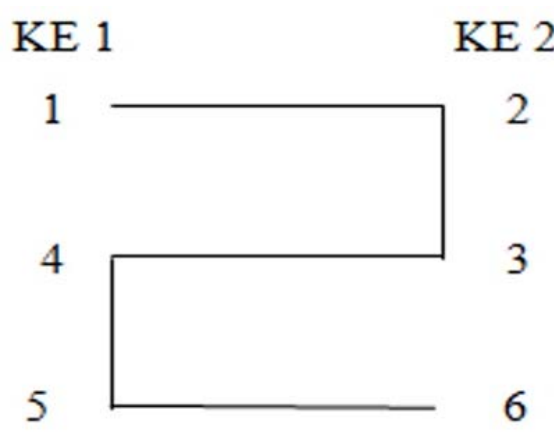

Fig. 2. Image of Ordinal Pairing 
Instrument of the Accuracy Of Kicking is stomach kick accuracy test. Test kicks 10 balls in a successive stop state towards the target which is 20 yards away. Four circles with a range of 4,8,12 and 16 feet respectively. The distance from the center of the circle to the boundary line is 20 yards, as shown in the picture. Tests long pass kick and the ball must bounce then land on the target. Each kick is scored according to the landing of the ball on the target. The ball that lands outside the target are scored 0 .

Each test is given a chance of two trials and each trial is 10 kicks. If the ball lands on the highest functioned circle line of the two circles. The test score is the number of numbers from both trials. Each ball that enters the target will be calculated according to the point where the ball falls [15] (Fig. 3).

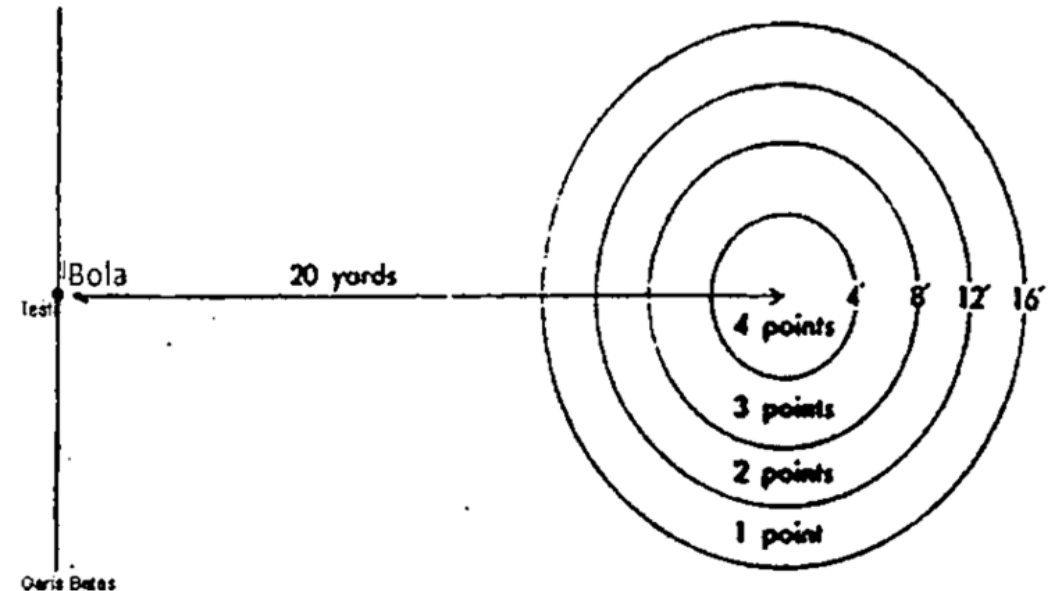

Fig. 3. Stomach Kick Accuracy Test

\subsection{Data Analysis}

Data were analyzed by t-test, but beforehand the prerequisite test was carried out beforehand. Testing the requirements of the analysis carried out is by reliability testing, normality test, and homogeneity test.

\section{Results and Discussion}

\subsection{Descriptive Statistics}

Descriptive Statistics of Progressive and Repetitive Part Methods is given in Tables 1, 2.

Table 1

Descriptive Statistics of Progressive Part Methods

\begin{tabular}{|c|c|c|}
\hline Descriptive Statistics & Pre-Test & Post-Test \\
\hline SUM & 500.0 & 522.0 \\
\hline AVG & 33.333 & 34.800 \\
\hline SD & 6.565 & 6.753 \\
\hline
\end{tabular}

Descriptive Statistics Repetitive Part Methods

\begin{tabular}{|l|l|l|}
\hline Descriptive Statistics & Pre-Test & Post-Test \\
\hline SUM & 499.0 & 548.0 \\
\hline AVG & 33.267 & 36.533 \\
\hline SD & 6.573 & 6.413 \\
\hline
\end{tabular}

\subsection{Test Reliability}

In order to find out the level of stability of the test results on the accuracy of the long pass kicks, a reliability test was carried out (Mulyono, 2010: 49). The results of the initial test and final test reliability tests conducted in this study shown in Table 3 .
Table 3

Preliminary and Final Test Reliability Test Results

\begin{tabular}{|c|c|c|}
\hline Test & Reliability & Category \\
\hline early & 0.878 & Acceptable \\
\hline end & 0.904 & Very Good \\
\hline
\end{tabular}

\subsection{Normality Test}

The normality test of the data in this study used the Lilliefors method. The results of the data normality test performed on each group are shown in Table 4.

Table 4

Normality Test Results

\begin{tabular}{|c|c|c|c|c|}
\hline Group & Test & L-count & L-table & Conclusion \\
\hline \multirow{2}{*}{1} & early & .1454 & .22 & Normal \\
\cline { 2 - 3 } & end & .1611 & & Normal \\
\hline 2 & early & .1622 & & Normal \\
\cline { 2 - 3 } & end & .1794 & & Normal \\
\hline
\end{tabular}

\subsection{Homogeneity Test}

The homogeneity test was conducted to compare the results of the initial tests in groups 1 and 2 . If the two groups had similar variance, the two groups were confirmed to have originated from the same team, so that later the two groups had differences in the final test, the difference was caused by giving different treatments in each group.

The data homogeneity test results between group 1 (K1) and group $2(\mathrm{~K} 2)$ are as shown in Table 5 . 
Table 5

Homogeneity Test Results

\begin{tabular}{|l|l|l|l|}
\hline Test & F-count & F-table & Conclusion \\
\hline Early & 1.0027 & 2.48 & Homogeneous \\
\hline
\end{tabular}

5.5. Test Differences Before and After Treatment in Groups 1 and 2

Different test results before and after treatment in groups 1 and group 2, here are the results shown in Table 6.

Table 6

Different Test Results Before and After Treatment

\begin{tabular}{|c|c|c|c|c|c|}
\hline Group & Test & Mean & T-count & T-table & Conclusion \\
\hline 1 & \multirow{2}{*}{ Before } & 33.333 & \multirow{2}{*}{0.25} & \multirow{4}{*}{2.145} & \multirow{2}{*}{ No differen } \\
\hline 2 & & 33.267 & & & \\
\hline 1 & \multirow{2}{*}{ After } & 34.800 & \multirow{2}{*}{3.666} & & \multirow{2}{*}{ different } \\
\hline 2 & & 36.533 & & & \\
\hline
\end{tabular}

5.6. Difference Test of Early Tests and Final Tests in Group 1 and Group 2

Before and after treatment in groups 1 and group 2, here are shown in Table 7.

Table 7

Differential Test Results for Early Tests and Final Tests for Groups 1 and 2

\begin{tabular}{|c|c|c|c|c|c|}
\hline Group & Test & Mean & T-count & T-table & Conclusion \\
\hline 1 & Early & 33.333 & \multirow{2}{*}{5.735} & \multirow{2}{*}{2.145} & Significant \\
\hline 2 & End & 34.800 & & \multirow{2}{*}{ Significant } \\
\hline 1 & Early & 33.267 & \multirow{2}{*}{10.879} & 2.145 & \\
\hline
\end{tabular}

5.7. Test of the Increase Percentage Difference

Knowing the percentage increase in group 1 and group 2, can be done by counting in each group (Table 8).

Table 8

Test Results of Difference Percentage Increase

\begin{tabular}{|c|c|c|c|c|}
\hline Group & Mean Early & Mean End & Increase & Percentage \\
\hline 1 & 33.267 & 34.800 & 1.533 & $4.401 \%$ \\
\hline 2 & 33.333 & 36.333 & 3.200 & $9.788 \%$ \\
\hline
\end{tabular}

These results indicate that the repetitive method is better than the progressive method to improve the ability of the accuracy of long pass kicks. The use of the part method has a positive influence on the results of the long pass kicks accuracy. The results of this study can be used as a basis for consideration to improve the accuracy of the football kicking. The use of the part method can not only be applied or used in football sports, but can also be applied to other sports whose movement elements can be separated or cut part by part to facilitate improving the results of technical abilities.

\section{Conclusion}

1. Based on the data obtained before being given treatment, after being analyzed it obtained the value of $\mathrm{t}$ between the initial test in group I and the initial test group $\mathrm{II}=0.25$, while $\mathrm{t}_{\text {table }}=2.145$. Means there are no significant differences. Group I and group II are balanced before being given treatment. Between group I and group II depart from the same starting point, which means that after being given treatment there is a difference, it occurs because of differences in the treatment given.

The value of $t$ between the initial test and the final test is group $\mathrm{I}=5.735$ while $\mathrm{t}_{\text {table }}=2.145$, means that the null hypothesis is rejected, thus it can be concluded that there are significant differences between the results of the initial test and the final test in group I. the final test in group $\mathrm{II}=10,879$ while $\mathrm{t}_{\text {table }}=2,145$. It means that the null hypothesis is rejected, thus it can be concluded that there is a significant difference between the results of the initial test and the final test in group II.

2. The results of the difference test conducted on the results of the final test in group I and group II, obtained $\mathrm{t}_{\text {value }}=3.666$, while $\mathrm{t}_{\text {table }}=2.145$. It means that the null hypothesis is rejected, thus it can be concluded that after being given treatment, there is a significant difference between the final test results in group I and group II. Because before being treated the two groups departed from the same starting point, so the difference occurred because of differences in the treatment. Thus the hypothesis states "there are differences in the effect of progressive and repetitive part methods on the accuracy of the long pass kick of an Extracurricular Football Student.

Group I which is given treatment with the progressive part method has an increase percentage value of $4,401 \%$. Whereas in group II given the repetitive part treatment method has an increase in the percentage value of $9.788 \%$. 


\section{References}

1. Bompa, T. O. (1999). Periodization: Theory and Methodology of Training. Kendall Hunt Publishing Company, 413.

2. Aunurrahman (2012). Belajar dan Pembelajaran. Bandung: Alfabeta.

3. Malina, R. M. (2010). Early Sport Specialization. Current Sports Medicine Reports, 9 (6), 364-371. doi: http://doi.org/10.1249/jsr.0b013e3181fe3166

4. Magill, R. A. (2001). Motor Learning Concepts and Applications. Singapore: Mc Graw. Hall Book, 367.

5. Hillman, C. H., Erickson, K. I., Kramer, A. F. (2008). Be smart, exercise your heart: exercise effects on brain and cognition. Nature Reviews Neuroscience, 9 (1), 58-65. doi: http://doi.org/10.1038/nrn2298

6. Lee, T. M. C., Wong, M. L., Lau, B. W.-M., Lee, J. C.-D., Yau, S.-Y., So, K.-F. (2014). Aerobic exercise interacts with neurotrophic factors to predict cognitive functioning in adolescents. Psychoneuroendocrinology, 39, 214-224. doi: http://doi.org/10.1016/j.psyneuen.2013.09.019

7. Luxbacher, J.A. (2011). Sepakbola. Indonesian Translation Edition. Jakarta: PT Rajagrafindo Persada.

8. Dimyati \& Mudjiono (2006). Belajar dan Pengajaran. Jakarta: PT Rineka Cipta, 298.

9. Nurkhasan, F. (2017). Penerapan model pembelajaran tgt (teams games tournaments) untuk meningkatkan hasil belajar long pass dalam permainan sepak bola pada siswa kelas x mia 1 sma negeri 1 sukoharjo tahun ajaran 2016/2017. Surakarta. Available at: https://eprints.uns.ac.id/id/eprint/37865

10. Mielke, D. (2007). Dasar-Dasar Sepakbola. Indonesian Translation Edition. Bandung: Raya Expert.

11. Andersen, T. B., Dörge, H. C. (2011). The influence of speed of approach and accuracy constraint on the maximal speed of the ball in soccer kicking. Scandinavian Journal of Medicine \& Science in Sports, 21 (1), 79-84. doi: http://doi.org/10.1111/j.1600-0838.2009.01024.x

12. Dichiera, A., Webster, K. E., Kuilboer, L., Morris, M. E., Bach, T. M., Feller, J. A. (2006). Kinematic patterns associated with accuracy of the drop punt kick in Australian Football. Journal of Science and Medicine in Sport, 9 (4), 292-298. doi: http://doi.org/10.1016/j.jsams.2006.06.007

13. Gardasevic, J., Bjelica, D., Milasinovic, R., Vasiljevic, I. (2016). The effects of the training in the preparation period on the repetitive strength transformation with cadet level football players. Sport Mont, 14 (2), 31-33. Available at: http://www.sportmont.ucg.ac.me/?sekcija=article\&artid=1343

14. Sloane, E. (2004). Anatomy and Physiology an Easy Learner. Jakarta: Medical Book Publishers EGC.

15. Mulyono, B. (2012). Tests and Measurements in Physical Physical Education. Surakarta: Sebelas Maret University Press.

16. Bompa, T. O., Buzzichelli, C. (2018). Periodization-: theory and methodology of training. Human Kinetics, 381.

17. Bompa, T., Bompa, T. O., Carrera, M. (2005). Periodization training for sports. Human Kinetics, 272.

18. Sugiyono. (2018). Qualitative, Quantitative, and R\&D Research. Bandung: CV Alfabeta.

Received date 02.07.2019

Accepted date 22.07.2019

Published date 31.07.2019

Ardian Rahman, Sport Science, Postgraduate Program, Universitas Negeri Yogyakarta, Colombo str., 1, Karangmalang, Caturtunggal, Depok District, Sleman Regency, Special Region of Yogyakarta, Indonesia, 55281 E-mail: ardianrahman22@gmail.com

Suharjana, Sport Science, Sport Science of Faculty, Universitas Negeri Yogyakarta, Colombo str., 1, Karangmalang, Caturtunggal, Depok District, Sleman Regency, Special Region of Yogyakarta, Indonesia, 55281 E-mail: suharjana@uny.ac.id

Erick Burhaein, Faculty of Teacher Training and Education, Universitas Muhammadiyah Lampung, ZA. Pagar Alam Street, Labuhan, Labuhan Ratu, Kedaton sub-district, Bandar Lampung City, Lampung Province, Indonesia, 35132

E-mail: erick.burhaein@gmail.com 